\title{
NOTES ON THE FAUNA OF BRITISH GUIANA
}

\section{By Kenneth Smith}

In 1950, from January to July, I was in British Guiana making a collection of live zoological specimens, which went to certain zoological gardens in Britain. During those months I gained some impressions of the status of wild life in the Colony. It was not possible in such a short period to conduct any very thorough investigation, but my work allowed me excellent opportunities to make personal observations and inquiries into matters connected with fauna preservation in Guiana.

Much of my time was spent at base camp at Kissy, on the outskirts of Georgetown, but I made several journeys to the interior. I visited Berbice, and in May I spent two weeks collecting in the Pakaraima Mountains and in the Ireng valley of the Guiana-Brazil border.

During the first months of my trip I had as companions collecting with me, Messrs. G. M. Durrell and R. G. Lowes. Lowes left Guiana in March and Durrell left in April. I am indebted to them for information on their own observations in Guiana, also for useful discussions.

I think it is probably correct to say that no major dangers threaten Guiana wild life to-day; there are certainly no tragedies of mass extermination such as have occurred in African territories. The position of individual species will nced watching from year to year, particularly the status of the Harpy Eagle (Harpia harpyja), which may be considered as giving some cause for immediate concern. A detailed survey, covering the whole Colony and on an official basis, would be most uscful to find out if any species are actually at, or near, the danger level.

Over eighty per cent of the area of British Guiana is forest, much of it uninhabited or sparsely inhabited. Economic development of the interior is difficult; many parts are approachable only by long and difficult river journeys, or by the internal airways system which links Aitkinson Field (outside Georgetown) to a few tiny landing strips cut out of the bush or savannah. Increasing demands for new sources of raw materials may, however, force rapid commercial development in years to come. The present small timber, bauxite and gold extractions may be mere beginnings.

When I was in Guiana all wild birds were protected by law. The Curator of the British Guiana Museum, the Hon. Vincent 
Roth, O.B.E., told me that he was endeavouring to secure similar protective legislation for mammals, and possibly for fish and certain reptiles as well. Last August Mr. Roth wrote to me to say that the new Wild Life Protection Law had passed the Executive Council and was due to come before the Legislature.

Excellent educational work is done under Mr. Roth's control at the Museum, Aquarium and Zoological Gardens in Georgetown. The exhibits are popular with all races, especially among school children; East Indians and Chinese, Portuguese and native Amerindians, coloured and whites-all are interested visitors. The Assistant Curator at the Museum is Mr. Ram S. Singh, M.B.O.U., M.A.O.U. He has made valuable contributions to the knowledge of the Colony's bird life.

The following notes on certain species may be of interest :-

Great Anteater (Myrmecophaga jubata).-Specimens brought to my camp from the North-West, Demerara area, and Rupununi. Common on the savannahs. Usually not molested.

Tamandua (Tamandua tetradactyla).-A ppears to be abundant and widely distributed in forested country.

Pigmy Anteater (Cyclopes didactyla).--Sometimes known in Guiana as "Thank 'ee God", because of the "praying" attitude it adopts when raising its hooked front claws for defence. Not uncommon.

Giant Armadillo (Priodontes gigas).-Tracks found in Moruca area of the North-West District, also on open land near the Demerara River. Species eaten by Amerindians, who say that it is generally solitary in habits. Localized, but probably not uncommon.

Harpy Eagle (Harpia harpyja).--Trapped and killed at times. Apparently not common. A slightly injured bird was sent from the interior to the Georgetown Zoo while $I$ was in Guiana, and another bird arrived there later in the same year.

Hoatzin (Opisthocomus hoa $z$ in).-A - A bundant along the Abary and Mahaicony Rivers. Local opinion in Mahaicony area is that the species has increased its range in recent years. I saw very many along both banks of Mahaicony River, including young in nests. Seldom molested, I was informed that I was the first person known to take an interest in these birds in Mahaicony crecks.

Boatbill (Cochlearius cochlearius).--One specimen only brought to my camp from Mahaica flats. Apparently not common.

Tricolor Heron (Hydranassa tricolor tricolor).-Fairly common along coastal strip between Essequibo and Berbice cstuaries. Nests near Georgetown. 
Many mammals, particularly the Capybara, Paca and Tapir, are hunted for food, but there scems to be no undue reduction in their numbers. Capuchin and Squirrel Monkeys are plentiful, although many are captured to sell as pets. Red Howlers are numerous in the remote forests. Ocelot and Margay are common, but it is not easy to determine the status of the Jaguar ; jaguars are, of course, killed near the cattle ranches, and I can offer no opinion on the position of the interesting form of Black Jaguar which occurs in the savannah and broken forest districts.

The Bush Dog, or Karisisi is often regarded as extremely rare, but $I$ think this is incorrect. Inquiries $I$ made revcaled quite a number of reliable records of the species, both from Government officials and from natives. The Tayra, too, is not rare, and in the Colony it bears the odd name of Haka Tiger.

Mr. Iurrell tells me that he found the police were strict in enforeing the bird protection laws in the Suddie and Pomeroon areas. In places, however, the young of wading birds, including Scarlet Ibis, are taken for food. Many parrots and macaws are taken for caging, and in Georgetown no action appears to be taken in numerous cases where these birds (and small $\mathrm{r}$ species such as finches and tanagers) are openly shown as pets and exhibited in markets for sale.

Anacondas are common, often finding their way into the irrigation channels between the sugar plantations. That most handsome snake, the Emerald Tree Boa, is probably common enough in the forests. I received three specimens, and two were on exhibition at the Zoo in Georgetown. Guiana is a paradise for anyone interested in frogs and toads. Two fascinating species, examples of which I sent to London Zoo, are the Pied Poison Frog (Dendrobates leucomelas) and the Reticulated Frog (Antelopus flaiescens), both from the Pakaraima Mountains; both species are handsomely patterned in jet black and bright yellow. The Giant Marine Toad (Bufo marinus) is very common, and its vocal efforts at dusk resemble very closcly the purring of a motor-cycle engine.

\section{REVIEWS}

SELADANG AND ELEPHANT

Big Game of Malaya. By E. C. Folnander. Batchworth Press. 21s.

This is a book of natural history and hunting stories. Half is given to Bos gaurus, the Gaur or Seladang, and nearly all the remaining pages to the Indian Elephant. The tapir, and 